\author{
Dariusz Rolnik \\ (Uniwersytet Śląski w Katowicach) \\ https://orcid.org/0000-0002-7649-3142
}

\title{
Kariera polityczna Leonarda Marcina Świeykowskiego: od podsędka do wojewody - przypadek czy nowe zasady kształtowania się elit w czasach Stanisława Augusta?
}

The Political Career of Leonard Marcin Świeykowski: from a Subiudex to a Province Governor - a Coincidence or a Manifestation of New Principles of the Development of an Elite During Stanisław August's Reign?

\section{STRESZCZENIE}

Sposób kreowania elit może mieć wpływ na ich jakość. Tak też myślano często w czasach stanisławowskich. Widać to przy kreacji stronnictwa królewskiego przez Stanisława Augusta. Przykładem tego jest kariera Leonarda Marcina Świeykowskiego. Niekoniecznie o karierze decydowała uległość. Większe znaczenie miały takie cechy, jak: przedsiębiorczość, inteligencja, a dopiero na drugim planie były te, niejako tradycyjne, dobre urodzenie i dziedziczony majątek. Istotna była również postawa wyrażająca zainteresowanie dobrem państwa i współobywateli. To budowało pozycję polityka w prowincji, w której działał i skłaniało króla do współpracy z nim, a ta mogła takiej osobie przynieść godność senatorską. Wbrew pozorom ważnym łącznikiem między kreującym elitę polityczną Stanisławem Augustem a kandydatem do niej był wspólny - przynajmniej teoretycznie - sposób myślenia o budowie silnej Rzeczypospolitej i wolnym narodzie szlacheckim stojącym na jej czele, co było swoistym połączeniem idei silnej władzy królewskiej z republikańskimi przekonaniami ogółu obywateli.

Słowa kluczowe: Stanisław August, elity Rzeczypospolitej, życie publiczne, Leonard Marcin Świeykowski

Wielkość państwa i jego siła w epoce nowożytnej zależały od wielu czynników - stanu gospodarki, sprawności administracji, położenia geopolitycznego czy wielkości armii, przy czym trudno je wydzielać i mierzyć odrębnie. Mają jednakże wspólny mianownik: to ludzie stanowiący i decydujący o obrazie tych sfer w państwie, czyli jego elity, jakkolwiek 
byłyby definiowane, są osobami, w których zostały skumulowane władza, bogactwo i prestiż $\dot{ }^{1}$ Wydaje się, że właśnie w Rzeczypospolitej, ale też w ogóle w państwach „nieabsolutystycznych", elity odgrywały rolę szczególna, bowiem w dużej mierze od ich mocy, poziomu i zaangażowania $\mathrm{w}$ prace na rzecz ojczyzny, a także od ich poziomu intelektualnego i etycznego zależał stan oraz oblicze danego organizmu państwowego. Teza ta wydaje się trafna, jednakowoż problemem pozostaje badanie elit i to począwszy od pierwszego etapu, czyli ich zdefiniowania. Na potrzeby niniejszego studium uznano, że w omawianym okresie elity społeczeństwa tworzyli ci, którzy zaliczali się do grona senatorów i pełnili funkcje publiczne z wyboru, czyli posłowie i deputaci. To oni - choć można tu mieć pewne wątpliwości - generalnie lokowali się, w różnym oczywiście stopniu, w grupie tych mających władzę, bogactwo i prestiż. W przypadku Rzeczypospolitej czasów ostatniego króla kreowanie tej grupy wybranych było uzależnione w dużym stopniu od Stanisława Augusta, bowiem de facto to on nominował senatorów, a jego stronnicy wpływali na wybór posłów i deputatów. Przyjęciu takiego założenia, biorąc pod uwagę skalę zjawiska, nie zaprzecza udział w tej polityce osób trzecich, m.in. w różnych momentach ambasadorów moskiewskich. Uznając słuszność tej hipotezy, można się zastanawiać, jakimi kryteriami kierował się Stanisław August przy tworzeniu swego stronnictwa, a szerzej przy kreowaniu elit państwa polsko-litewskiego, a także według jakich kryteriów należy oceniać kondycję owej elity. Jakkolwiek dyskusyjne, to sensowne wydaje się wskazanie jako na podstawowe kryteria awansu w czasach stanisławowskich takich cech kandydatów, jak: przedsiębiorczość, inteligencja, stosunek do władcy, stosunek do państwa i współobywateli, pozycja w środowisku, a dopiero na drugim planie były to, niejako tradycyjnie, urodzenie i majątek. Niestety, brakuje badań szczegółowych na ten temat, potrzebnych do weryfikacji takiego sposobu pokazywania problemu. Niniejszy artykuł stanowi próbę uzupełnienia jedynie drobnej części tej luki.

Właściwie na wszystkie wyżej wymienione kryteria awansu czy zasług koniecznych do objęcia funkcji wskazywał Stanisław August, gdy odpowiadał na listy starających się o krzesła senatorskie, urzędy ministerialne czy funkcje poselskie i deputackie. Dla ostatniego króla najważniej-

1 Por. o dyskutowanej kwestii i definicji elit: A. Mączak, Rządzący i rządzeni. Władza i społeczeństwo w Europie wczesnonowożytnej, Warszawa 1986, s. 123-181; S. Ciara, Senatorowie i dygnitarze koronni w drugiej połowie XVII wieku, Wrocław-Warszawa-Kraków 1990, s. 169-175; T. Zielińska, Magnateria polska epoki saskiej, Wrocław 1977, s. 10-78. Szersze definicje i rozważania niehistoryków, np.: Cz. Znamierowski, Elita i demokracja, Warszawa 1946, s. 5-33; M. Stefaniuk, Teoria elit Vilfreda Pareta, Lublin 2001, s. 52-60, 129-133, 147-155, 173-180. Cała kwestia to osobny problem i wymaga odrębnego potraktowania. 
sze było zapewne oddanie dla jego polityki, jednakże nie wyrażał tego wprost, a co najwyżej łączył taką sugestię - trzeba przyznać, że przynajmniej werbalnie bardzo dobrze $-\mathrm{z}$ określonymi przymiotami danej osoby i z wyrażeniem przez nią wyraźnej deklaracji podjęcia służby dla Rzeczypospolitej. W hierarchii Stanisława Augusta kolejnym, jeśli chodzi o wagę, kryterium przy wspieraniu ubiegających się o awanse była ich pozycja w środowisku. Po spełnieniu tych pierwszych kryteriów kolejne dawały sporą szansę na awans. Kwestie majątku i urodzenia, jakkolwiek cały czas ważyły - i nie można było ich zupełnie wyrugować w czasach stanisławowskich - to jednak decydowały tylko w przypadku nominacji na najwyższe urzędy ministerialne i najważniejsze krzesła senatorskie, natomiast przy niższych dygnitarstwach miały zdecydowanie mniejsze znaczenie. Taki schemat tworzenia stronnictwa królewskiego jawi się z opracowań poświęconych panowaniu Stanisława Augusta. W generaliach jest on trafny, ale umyka w nich elastyczność działań ostatniego króla Rzeczypospolitej w tych dążeniach, a także domniemany portret owego dobrego kandydata do takiej roli.

Wybrana jako przykład do analizy mechanizmu kreowania nowych elit w czasach panowania ostatniego króla kariera Leonarda Macieja Świeykowskiego (1721-1793) herbu Trzaska zdaje się pokazywać dokładniej funkcjonowanie wskazanego mechanizmu kariery publicznej w Rzeczypospolitej i istotność cech preferowanych u kandydatów do nominacji na najważniejsze urzędy w państwie. Ostatni wojewoda podolski wywodził się z ubogiej szlachty, był synem pułkownika Macieja Świeykowskiego i Zofii Świeykowskiej z Omiecińskich². Swą karierę, zarówno polityczną, jak i równoległą ekonomiczną rozpoczynał ok. 1743 r. w środowisku Lubomirskich, Stanisława starosty sądeckiego i podstolego koronnego oraz Józefa podstolego litewskiego. Dał się tu poznać jako sprawny zarządca ich majątków i dobry prawnik. Dzięki Lubomirskim wszedł też w orbitę „Familii", co pozwoliło mu udzielać się także w sprawach gospodarczych i procesowych Czartoryskim oraz Poniatowskim ${ }^{3}$. W 1759 r. poznał Stanisława Poniatowskiego, wówczas stolnika litewskiego ${ }^{4}$, a sam w tym

2 Por. D. Rolnik, Leonarda Marcina Świeykowskiego (1721-1793) ostatniego wojewody podolskiego życie codzienne i publiczne oraz jego myśli o Rzeczypospolitej, Katowice 2016, s. 37, 50.

3 Por. np. Biblioteka PAN w Kórniku [dalej: BK], rkps 1246, nl., Akta sądowe województwa bracławskiego. O Lubomirskich i ich relacjach z L.M. Świeykowskim por.: W. Szczygielski, Lubomirski Stanisław, w: Polski Słownik Biograficzny [dalej: PSB], t. 18, Wrocław 1973, s. 50-53; Tomasza Święckiego historyczne pamiątki znamienitych rodzin i osób dawnej Polski, t. 2, oprac. J. Bartoszewicz, Warszawa 1859, s. 467; D. Rolnik, Leonarda Marcina, s. 355-356.

4 Por. Biblioteka Książąt Czartoryskich w Krakowie [dalej: BCz.], rkps 682, s. 457, Stanisław August do L.M. Świeykowskiego, Warszawa 27 XII 1777. 
czasie, od 1750 r., pozostawał skarbnikiem trembowelskim i dopiero później został podsędkiem bracławskim ${ }^{5}$, co, mimo że nie przyczyniało mu splendoru, to dawało pewną wymierną władzę. L.M. Świeykowskiego wspierali także Sanguszkowie, o czym świadczy to, że w latach 1764-1766 wystąpili obok niego w słynnym procesie z Bogdanowiczami ${ }^{6}$.

Leonard Marcin Świeykowski na drogę posługi publicznej wstąpił w 1762 r., kiedy został wybrany na deputata - m.in. dzięki wsparciu Augusta Czartoryskiego - do Trybunału Koronnego, na którym reprezentował księcia podstolego koronnego Stanisława Lubomirskiego. Pełniąc swą funkcję deputacką w Lublinie, L.M. Świeykowski był przypuszczalnie jednym z pierwszych, który doniósł „Familii” o „nagłej” śmierci Augusta III i zabiegach elektora saskiego o koronę po nim ${ }^{7}$. Wracając z Lublina z Trybunału, odwiedził Puławy, gdzie poznał stolnika litewskiego Stanisława Poniatowskiego. W Puławach spotkał się również z Kazimierzem Poniatowskim ${ }^{8}$. W 1764 r. Świeykowscy wspierali politykę „Familii” i byli przez nią wykorzystywani do wielu posług9. Kasztelan wiski Kazimierz Karaś pisał, że A. Czartoryskiemu „się ta cała familia zawsze przydać może"10. L.M. Świeykowski, jak chyba cała jego rodzina, w 1764 r. zdecydowanie opowiedział się za elekcją Stanisława Augusta, pod którą podpisało się dwóch jego braci - Michał i Józef, a on sam, jakkolwiek brakuje jego podpisu pod elekcją, był zwolennikiem Stanisława Augusta ${ }^{11}$ mającym już w jego środowisku pewne wpływy, o czym świadczy przypadek Marcina Matuszewicza, który dzięki L.M. Świeykowskiemu pośrednio zyskał dostęp do Michała Fryderyka Czartoryskiego, księcia kanclerza litewskiego ${ }^{12}$.

W następnych latach po elekcji Stanisława Augusta L.M. Świeykowski utrzymywał z „dworem królewskim” stosunki poprawne. Chociaż

5 Por. D. Rolnik, Leonarda Marcina, s. 356; Urzędnicy podolscy XIV-XVIII wieku. Spisy, oprac. E. Janas, W. Kłaczewski, J. Kurtyka, A. Sochacka, Kórnik 1998, s. 236.

6 Por. D. Rolnik, Leonarda Marcina, s. 113-128.

7 Por. ibidem, s. 355-360.

8 Por. ibidem, s. 360.

9 Por. BK, rkps 1264, k. 2, [?] Konigfeld do [L.M. Świeykowskiego], Warszawa 30 XII 1762; ibidem, k. 4, Kazimierz Poniatowski podkomorzy koronny do łowczego [trembowelskiego J. Świeykowskiego], Warszawa 18 I [1764?]; ibidem, k. 10-11, [kasztelan wiski K. Karaś?] do NN [J. Świeykowskiego?], b.m. 14 II 1765.

10 Por. ibidem, k. 10-11, [K. Karaś] do NN, b.m. 14 II 1765. O K. Karasiu i jego roli w środowisku Stanisława Augusta por.: M. Rymszyna, Karaś Kazimierz, w: PSB, t. 12, Wrocław 1966-1967, s. 19. O dalszych zasługach Świeykowskich dla Poniatowskich por.: D. Rolnik, Leonarda Marcina, s. 360-364.

11 Por. D. Rolnik, Leonarda Marcina, s. 364-365.

12 M. Matuszewicz, Diarusz życia mego, t. 2, oprac. B. Królikowski, Z. Zielińska, Warszawa 1986, s. 550. 
zyskał wsparcie króla w procesie z Bogdanowiczami, to jednak do początku lat siedemdziesiątych XVIII w. politycznie mniej się udzielał na rzecz dworu - owszem, w Warszawie bywał, ale bynajmniej nieaktywny. Czas konfederacji barskiej wyraźnie wstrzymywał jego aktywność i na scenie politycznej ponownie pojawił się w $1772 \mathrm{r}$. Był wtedy po pierwszym konflikcie ze Stanisławem Augustem - ten jednak mu wybaczył. Co było powodem rozdźwięków, tego nie wiemy, ale przypuszczalnie były to kwestie polityczne związane z konfederacją barską i I rozbiorem $^{13}$. L.M. Świeykowski z pewnością nie był pokornym sługą ani króla, ani Lubomirskich, z którymi jego relacje też wówczas się rozluźniły i być może to właśnie sprawiło, że ponownie został zauważony przez Stanisława Augusta. W 1772 r. rozpoczął starania o elekcję na urząd sędziego bracławskiego, jednakże nie było w tym widać jego desperacji; sugerował nawet, że wybory powinny się odbyć później, a nie „gdy Ojczyzna dzisiaj $w$ tak wielkim zamieszaniu zostaje" ${ }^{\prime 14}$. Należy jednak zauważyć, że był to rok przełomowy w jego karierze, bowiem 28 października przy poparciu Stanisława Augusta i reprezentującego go Józefa Stempkowskiego oraz z pomocą A. Czartoryskiego wojewody ruskiego, a przeciw Grocholskim, został wybrany na urząd sędziego bracławskiego ${ }^{15}$. Od tego momentu do czasów uchwalenia Konstytucji 3 maja wspierał politykę króla. Można go z pewnością zaliczyć do stronnictwa królewskiego, co sam zresztą deklarował w 1778 i 1785 r., kiedy to pisał do Stanisława Augusta, że będzie go wspierał bez względu na okoliczności ${ }^{16}$. Niemniej jednak do swych politycznych obowiązków podchodził z dystansem, nie stał się typem polityka sejmikowego i raczej od życia sejmikowego stronił, zyskując natomiast uznanie jako sędzia bracławski ${ }^{17}$.

W 1776 r. Stanisław August rozważał wyniesienie go do godności wojewody inflanckiego i został podany przez Radę Nieustającą jako

${ }^{13}$ Już w 1769 r. król pomógł w zabezpieczeniu majątków L.M. Świeykowskiego przez księcia Dimitrija? Golicyna. Por. BCz., rkps 685, s. 525, L.M. Świeykowski do Jacka Ogrodzkiego, Nowosiek 5 XI 1769, a w 1771 r. przesyłał prośby w sprawie wsparcia osób trzecich, por. np. BCz., rkps 685, s. 531, L.M. Świeykowski do [Stanisława Augusta], b.m. 27 X 1771. Por. D. Rolnik, Leonarda Marcina, s. 365-371.

${ }_{14}$ BCz., rkps 710, s. 170, L.M. Świeykowski do J. Stempkowskiego, Żabokrzyca 5 VII 1772. List ten przesłał królowi J. Stempkowski. Por. ibidem, J. Stempkowski do J. Ogrodzkiego, Trojanów 16 VII 1772.

15 Por. D. Rolnik, Leonarda Marcina, s. 372-375.

16 Por. BCz., rkps 685, s. 534, L.M. Świeykowski do Stanisława Augusta, Bilczyn? 16 V 1778. Por. o bliskich związkach L.M. Świeykowskiego z królem w następnych latach: Biblioteka Zakładu Narodowego im. Ossolińskich we Wrocławiu [dalej: BO], rkps 1996, k. 107, 235, W. Gurski do L.M. Świeykowskiego, Warszawa 4 I 1785 i 22 III 1786.

17 Por. Biblioteka Narodowa w Warszawie [dalej: BN], rkps 9050, t. 1, k. 92-92v, T. Lipski prezydujący w Radzie Nieustającej do L.M. Świeykowskiego, Warszawa 30 XI 1776. 
kandydat ${ }^{18}$, L.M. Świeykowski nawet przybył wówczas do Warszawy ${ }^{19}$. Nadzieje okazały się jednak płonne, i, co więcej, doszło wtedy ponownie do rozdźwięków między królem a sędzią bracławskim, których przyczyną była prawdopodobnie porażka $w$ dążeniu do tej godności senatorskiej. Jednakże nie jest to informacja potwierdzona, mogło też chodzić o burzliwy sejm 1776 r. z udziałem wojsk rosyjskich, a należy podkreślić, że Rosjan L.M. Świeykowski tylko tolerował, owszem, korzystał z ich pomocy, lecz za sojuszników nigdy nie uważał ${ }^{20}$. Natomiast pewne jest, że do pogodzenia się zwaśnionych stron doszło w 1777 r., wówczas też Stanisław August zalecił L.M. Świeykowskiemu opiekę nad sejmikami, za co obiecał swe względy ${ }^{21}$. Za jego pośrednictwem Stanisław August chciał wpływać też na Stanisława Szczęsnego Potockiego, co długo się udawało. Bez wątpienia łączenie L.M. Świeykowskiego ze S.Sz. Potockim było dla sędziego bracławskiego korzystne, bowiem mając już silną pozycję ekonomiczną na bracławszczyźnie, zaliczał się do grona najbardziej wpływowych osób na ziemiach ukrainnych i sam również miał swych zaufanych ludzi w Warszawie, także w otoczeniu króla ${ }^{22}$. To wszystko sprawiło, że stopniowo powstawał wizerunek L.M. Świeykowskiego jako naprawdę dobrego obywatela. Tak zbudowana pozycja była po części wynikiem wsparcia królewskiego, ale także własnych wysiłków i prawego charakteru L.M. Świeykowskiego, co pokazał jako sędzia bracławski w służbie publicznej, niejednokrotnie wchodząc w spór prawny z wymienionymi wyżej politycznymi sojusznikami. Napięcia te jednak potrafił umiejętnie łagodzić i kończyć ugodami, nie tracąc przy tym autorytetu. Można też zauważyć, że w gronie przyjaciół L.M. Świeykowskiego dominowały osoby związane ze Stanisławem Augustem, niemniej jednak były też postacie, które, będąc w opozycji do króla, uznawały obiektywnie pozycję sędziego bracławskiego i szanowały jego zdanie, łagodząc wobec niego swe negatywne nastawienie do króla, co zdarzyło się nawet Franciszkowi Ksaweremu Branickiemu, który, jak się wydaje, bezskutecznie zabiegał o przyjaźń L.M. Świeykowskiego.

18 Por. Tomasza Święckiego historyczne pamiatki, t. 2, s. 467.

19 Por. BK, rkps 1256, t. 1, k. 89, Gabriel Peretiakowicz do L.M. Świeykowskiego, Moskalówka 17 XII 1776.

20 Por. D. Rolnik, Leonarda Marcina, s. 378-379.

21 Por. ibidem, s. 381-382.

22 Por. ibidem, s. 391. Por. też A. Rosner, Mniszech Michat Jerzy Wandalin (1742-1806), w: PSB, t. 21, Wrocław 1976, s. 480-483; Biblioteka Jagiellońska w Krakowie [dalej: BJ], rkps 5971, k. 148, I. Świeykowska do [męża L.M. Świeykowskiego], Kołodno 8 VI 1783; BCz., 3185, s. 671, 675, 679, 687, M.J. Mniszech do L.M. Świeykowskiego, Warszawa 31 VII, 14 VIII, 25 IX 1783, 25 III 1785; BK, rkps 1273, k. 64, [S.] Badeni do L.M. Świeykowskiego, Korsuń 23 V 1779; BO, rkps 1997, k. 18, [S.] Badeni do L.M. Świeykowskiego, Horchów? 5 IV 1785[3]; BO, rkps 1996, k. 95v, [W.] Gurski do L.M. Świeykowskiego, Warszawa 16 XII 1784. 
Znamienne są słowa samego L.M. Świeykowskiego, który w 1777 r. - będąc z nim jeszcze w nie najlepszych relacjach - pisał do króla, że już za przeszłego panowania przylgnął do „Familii”: „,[...] w czasach dla niej przeciwnych, nie z powodu jakowego datku, albo jakowych dóbr dzierżawienia /:bo takowych łask dotąd nie znam:/ ale z tego jedynie powodu, i w tej nadziei, że służąc J.O. Familii zasłużyć się miałem WKM"23. Król na tę deklarację współpracy odpowiedział mu miłym listem, w którym napisał, że zna i ceni jego charakter oraz przymioty od dawna ${ }^{24}$. W istocie tam, gdzie w sprawach publicznych mógł, to dla dobra ogółu i Rzeczypospolitej L.M. Świeykowski wspierał króla, chociaż nie ulega wątpliwości, że miał też swoje ambicje i silnie rozbudowane poczucie sprawiedliwości, nie szukał jednak na siłę swego wyniesienia. Wszelako w dużym stopniu jego bierność zadecydowała, że nie został w 1778 r. posłem ${ }^{25}$, ale z drugiej strony poczuł się urażony, że go nie wybrano i być może stąd wynikała jego późniejsza mniejsza aktywność. Jednakże taka polityka L.M. Świeykowskiego - trudno ocenić na ile uprawiana świadomie - okazała się dla niego korzystna, być może za ową wstrzemięźliwość czekała go nagroda.

W 1782 r. L.M. Świeykowski został deputatem, a niedługo potem marszałkiem Trybunału Koronnego, na co ewidentny wpływ miał Stanisław August, który wskazał na niego jako na kandydata na marszałka jeszcze na długo przed obiorem deputatów. Najistotniejsze w tym jest, że kandydatura ta zyskała powszechną akceptację. Po upływie kadencji sprawowania tej zaszczytnej funkcji został kasztelanem kamienieckim ${ }^{26}$. Był to pierwszy urząd senatorski w jego rodzinie, za który bardzo gorąco i chyba szczerze dziękował Stanisławowi Augustowi ${ }^{27}$. Jednakże te oświadczenia nie zostały poparte jego konkretnym działaniem i jako senator nie pojawił się ani razu na sejmie, zresztą i na sejmikach także bywał rzadko. Tymczasem taka postawa niezaangażowania, jak się wydaje, jeszcze wzmocniła jego autorytet, gdyż bywał postrzegany jako ten, który, gdy tylko się pojawił na sejmiku, był władny na kresach przeforsować wszystko. Tak w istocie

${ }^{23}$ Por. BCz., rkps 682, s. 456 [błędy w paginacji], L.M. Świeykowski do Stanisława Augusta, b.m. 15 XI 1777.

${ }^{24}$ Por. ibidem, s. 457 [błędy w paginacji], Stanisław August do L.M. Świeykowskiego, Warszawa 27 XII 1777.

25 Por. Archiwum Narodowe w Krakowie [dalej: AN Kr.], Archiwum Sanguszków [dalej: A.Sang.], Korespondencja rkps 36, s. 637, M. Walewski do H. Sanguszki, Kosieck 26 IX 1778; W. Filipczak, Sejm 1778 roku, Warszawa 2000, s. 89.

26 Por. D. Rolnik, Leonarda Marcina, s. 399-419. Por. też Deputaci Trybunatu Koronnego 1578-1794. Spis, cz. 5: 1751-1794, oprac. J. Ternes, Warszawa 2017, s. 247, 250.

27 Por. BCz., rkps 688, s. 791, 797, L.M. Świeykowski do Stanisława Augusta, [Lublin] 11 i 14 IX 1783. Por. też BCz., rkps 3185, s. 679, J. Małachowski do L.M. Świeykowskiego, [Warszawa] 25 IX 1783. 
się stało na sejmiku poselskim latem 1788 r., gdy w porozumieniu ze Stanisławem Augustem przeprowadził elekcję posłów w Kamieńcu ${ }^{28}$. W czasie Sejmu Wielkiego - nie ruszając się wiele ze swego Kołodna - wspierał reformy do momentu uchwalenia Konstytucji 3 maja i dopiero gdy upewnił się, że poparł ją Stanisław August, jego drogi z królem rozeszły się - odtąd uważał go za wroga Rzeczypospolitej dążącego do absolutyzmu. Wcześniej, jeszcze w listopadzie 1790 r., zdążył zostać wojewodą podolskim, czym król chciał go skłonić do wiernego trwania przy nim, co się jednak nie udało ${ }^{29}$.

Co najmniej od 1772 r. kariera L.M. Świeykowskiego, wyraźnie wspierana przez Stanisława Augusta, była, jak się wydaje, jego przemyślaną grą i dobrym wyborem. Do 1791 r. był on skutecznym, choć może za bardzo niewidocznym, obrońcą racji królewskich, co z przesadą zauważał Eustachy Heleniusz, gdy pisał: przez okres 11 lat „trzymania krzesła senatorskiego" do śmierci w 1793 r. L.M. Świeykowski „w województwie [bracławskim] sprawami publicznemi głównie sam kierował $\mathrm{w}$ duchu St. Augusta; był mu najzupełniej poświęcony", rozdawnictwo urzędów i orderów w tym województwie od niego zależało, a na sejmikach potrafił utrzymać większość „dla partyji królewskiej”30.

Droga L.M. Świeykowskiego do godności senatorskiej - choć sama w sobie może wydawać się błyskotliwa, bo przecież, upraszczając sprawę, bez prekursorów i bez majątku w ciągu 20 lat doszedł do senatu - była $\mathrm{w}$ istocie wynikiem jego ciężkiej pracy na różnych frontach - ekonomicznym i politycznym. Tę jego pracowitość, a przy tym niewątpliwe przymioty osobiste, sprawiedliwość, wytrwałość, ale też umiejętności i zdolności dostrzegł w nim Stanisław August. Wszystkie te cechy modelowo pasowały do wyobrażeń, jakie miał król i jego najbliższe otoczenie o dobrym dla Rzeczypospolitej polityku. Postawienie na L.M. Świeykowskiego, jak

28 Por. BCz., rkps 3186, s. 629, 633, I. Czartoryska do L.M. Świeykowskiego, Puławy 12 i 28 VII b.r. [1788]; BJ, rkps 5971, k. 272, L.M. Świeykowski do [M.] Staniszewskiego, Kołodno 4 VIII 1788; Korespondencja krajowa Stanisława Augusta z lat 1784 do 1792, wyd. B. Zaleski, Poznań 1872, s. 99-101; A.J. Czartoryski, Pamiętniki i memoriały polityczne 1776-1809, oprac. J. Skowronek, Warszawa 1986, s. 98; M. Handelsman, Czartoryski Adam Jerzy, w: PSB, t. 4, Kraków 1938, s. 258; J. Michalski, Sejmiki poselskie 1788 roku, w: idem, Studia historyczne z XVIII i XIX wieku, t. 1, Warszawa 2007, s. 240-243; A. Stroynowski, Opozycja sejmowa w dobie rządów Rady Nieustajacej. Studium z dziejów kultury politycznej, Łódź 2005, s. 65.

${ }_{29}$ Por. Lvivska Naukowa Biblioteka Ukrainy i. W. Stefanyka [dalej: LNB], f. 141, op. 3, rkps 438, s. 25, Wywód szlachectwa Świeykowskich; K. Pułaski, Kronika polskich rodów szlacheckich Podola, Wotynia i Ukrainy, t. 2, oprac. T. Epsztein, S. Górzyński, Warszawa 1991, s. 219. Sam L.M. Świeykowski pisał: „[...] oryginalny przywilej na województwo mnie służący iuż w Kamieńcu oblatowany"; BJ, rkps 5971, k. 445, L.M. Świeykowski do M. Staniszewskiego, Kołodno 17 XII 1790.

30 Por. E. Heleniusz [E. Iwanowski], Rozmowy o polskiej koronie, t. 1, Kraków 1873, s. 531. 
się dziś wydaje, było posunięciem trafnym i bynajmniej niealtruistycznym ze strony króla, nie wynikało również z zafascynowania Stanisława Augusta osobowością późniejszego wojewody podolskiego. L.M. Świeykowski poza osobistymi przymiotami, o których już wspomniano, miał rozbudowaną i ustosunkowaną $\mathrm{w}$ województwie rodzinę, a także niemały majątek, sytuujący go w latach osiemdziesiątych XVIII w. w pierwszym rzędzie najmożniejszych rodzin kresowych. W tym kontekście zapewnienia L.M. Świeykowskiego kierowane do króla, że jego sprawy będzie wspierał "z całym domem”, miały swe znaczenie ${ }^{31}$.

Czasy stanisławowskie charakteryzowały się wzmożeniem dyskusji merytorycznej, choć często tylko teoretycznej i ideologicznej, były też próbą tworzenia programu naprawy Rzeczypospolitej, którego realizacja stawała się podstawą dążenia Stanisława Augusta i jego najbliższego otoczenia w kierunku kreowania nowej elity. Taka zmiana, czy też chęć jej dokonania, rysuje się w korespondencji osób związanych ze Stanisławem Augustem, w której widoczna jest ich motywacja do jej tworzenia i z której wyłania się typ polityka-obywatela, mającego stanowić o sile nowej elity na tyle skutecznej, aby zmienić i naprawić Rzeczpospolitą. Na to zapotrzebowanie odpowiadali też zainteresowani obywatele, którzy wyraźnie artykułowali i wskazywali na te same argumenty, które miały otwierać drogę do służby publicznej - kariery ${ }^{32}$.

Intencje Stanisława Augusta były w tej przestrzeni życia publicznego dość jasne. W swych listach wysyłanych do osób ubiegających się o wyróżnienia zawsze informował - szczerze bądź nieszczerze - jakiego kandydata widziałby na danym stanowisku. W owych deklaracjach pojawiało się wskazanie, że wybrałby kandydata oddanego Rzeczypospolitej. Chyba nie zawsze, a szczególnie już po I rozbiorze, była to li tylko pusta retoryka. Większość starających się o wywyższenie, nagrodę czy urząd u Stanisława Augusta to osoby, które obiecywały i wyrażały swe poparcie dla projektów króla. Formuły, jakich używały, stawały się oczywistością być może więc król i ludzie z nim związani, nie zawsze ufając takim zapewnieniom, starali się je weryfikować, a czasem sami poszukiwali odpowiednich kandydatów przez tych, którym ufali i w ten sposób krąg oddanych królowi i jego polityce się powiększał. Przykładem takiego działania są wysiłki brata kró-

31 Por. BCz., rkps 685, s. 534, L.M. Świeykowski do Stanisława Augusta, Bilczyn? 16 V 1778.

32 Por. D. Rolnik, Sejmiki poselskie drugiej połowy panowania Stanistawa Augusta. O czynnikach i motywacjach decydujacych o wyborze posłów sejmowych, w: Po unii-sejmiki szlacheckie w Rzeczypospolitej XVI-XVIII wieku, red. H. Lulewicz, M. Wagner, Siedlce 2013, s. 331-355. 
lewskiego Michała Poniatowskiego ${ }^{33}$. Stanisław August rozważał też, „nie tylko formalnie", na ile kandydat spełniał stawiane mu warunki. Przykładem tego może być sprawa kandydatury do funkcji poselskiej Karola Kownackiego, którą chcieli zdyskredytować jego przeciwnicy, wskazując, że nie ma on właściwych cech do jej pełnienia ${ }^{34}$. Także refleksja zdecydowała o odrzuceniu od kandydowania do funkcji posła w 1778 r. bliskiego krewnego stronnika królewskiego łowczego płockiego Ludwika Zielińskiego, przy czym towarzyszyła temu wyraźna perswazja: „,...] jest to moment kochany łowczy, który nas albo złączyć, albo rozłączyć na zawsze może" ${ }^{\prime \prime 35}$. Również nie od razu funkcje zyskiwali synowie L.M. Świeykowskiego, musieli bowiem zostać najpierw uznani za zdatnych do ich pełnienia, co bynajmniej nie znaczy, że musieli być tylko powolnymi królewskiej woli, o czym świadczy przykład Jana Nepomucena Świeykowskiego, który został deputatem, mimo że wcześniej krytykował króla ${ }^{36}$.

Zasady awansów w Rzeczypospolitej stanisławowskiej klarował jasno M. Poniatowski: najpierw „wiek”, rozumiany nie dosłownie, ale jako nabyte doświadczenie, dalej "talenta”, a następnie zasługi ${ }^{37}$. Według tych kryteriów dokonywano pierwszej, zasadniczej selekcji kandydatów do urzędów i funkcji, potem zaś uszczegóławiano kryteria doboru. Do stronnictwa starano się dobierać ludzi energicznych, niekoniecznie jednak młodych i niepochodzących znikąd, takowego trzeba było najpierw po$z_{n a c ́}^{38}$. Osoba, której miano powierzać funkcje czy urzędy, musiała pokazać, że należy do "godnych i cnotliwych", bowiem tylko taką można było obdarzyć zaufaniem ${ }^{39}$. Tu niekiedy „talenta” mogły przeważyć zarówno

33 Por. Archiwum Główne Akt Dawnych [dalej: AGAD], Archiwum Ekonomiczne prymasa Poniatowskiego [dalej AEP], rkps 121, k. 42, [bruliony] M. Poniatowski do M. Podoskiego, [Płock] 7 VII 1784; M. Poniatowski do [K.] Wołowicza marszałka słonimskiego, [Płock] 5 VII 1784; ibidem, k. 42v, M. Poniatowski do [J.] Makowieckiego podkomorzego słonimskiego, [Płock] 5 VII 1784.

${ }^{34}$ BCz., rkps 922, s. 823-825, K. Kownacki do Stanisława Augusta, [Warszawa] 21 VII 1786.

35 AGAD, AEP, rkps 121, k. 43v, M. Poniatowski do [L.?] Zielińskiego, [Płock] 11 VIII 1784. Zieliński się z tym pogodził, a jego imiennik otrzymał jako rekompensatę wójtostwo od króla, ibidem, k. 44v, M. Poniatowski do [?] Zielińskiego, [Płock] 23 VIII 1784.

$36 \mathrm{Za}$ naturalne uważał to ich ojciec, bynajmniej nie miał o to pretensji do króla, prosił dla nich o nagrody, ale po odbytych przez nich funkcjach, BCz., rkps 730, s. 851, L.M. Świeykowski do Stanislawa Augusta, Dubno 27 I 1791. Por. inne przykłady wstrzymanych karier synów zasłużonych dla króla: BCz., rkps 737, s. 133-134, Kazimierz Wolmer do Stanisława Augusta, Grodno 7 II 1783.

37 AGAD, AEP, rkps 121, k. 21, M. Poniatowski do L. Zielińskiego, [Płock] 17 XII 1782.

38 Ibidem, k. 43, M. Poniatowski do Gabriela Karwosieckiego podkomorzego płockiego, [Płock] 11 VIII 1784.

39 Ibidem, k. 28, M. Poniatowski do Józefa Klemensa Mielżyńskiego wojewody kaliskiego, [Płock] 15 VI 1783. 
nad deklaracją lojalności, jak i nad urodzeniem ${ }^{40}$, natomiast dostrzegana bezczynność dyskwalifikowała daną osobę od pełnienia funkcji, ponieważ trudno, by taka miała zasługi w „publiczności” ${ }^{41}$.

Dobrze było - co bynajmniej nie stało w sprzeczności z powyższą uwaga, to jakby inna płaszczyzna oceny kandydata - gdy zauważono, że wskazany kandydat był świadom komu namaszczenie zawdzięcza. $\mathrm{Z}$ tą starą zasadą nie starano się usilnie walczyć - tak jak w dawnych czasach, tak i w czasach stanisławowskich wdzięczność jako czynnik decydujący o wyniesieniu dalej była ważna - było to widoczne $\mathrm{w}$ awansach L.M. Świeykowskiego. W dalszym ciągu znaczenie miała również moc rodziny, jej nazwisko, niekiedy trudno było takiego kandydata pominąć, wszak i wówczas starano się uzasadnić jego wybór racjonalnymi przesłankami zgodnymi przynajmniej $\mathrm{w}$ warstwie frazeologicznej $\mathrm{z}$ celami darczyńcy - króla. Tak się stało w przypadku młodego Jana Małachowskiego, starosty opoczyńskiego. Podkreślano wówczas, że "talenta” danej osoby oraz jej rodzinne konotacje przeważały nad młodym wiekiem i to niejako zdecydowało o jego elekcji na posła w 1784 r., pomimo że początkowo chciano go skłonić do nieubiegania się o tę funkcję. M. Poniatowski pogratulował mu wówczas "prawdziwie otrzymanego zwycięstwa” w tak młodym wieku ${ }^{42}$. Istotne było jednak to, że nawet taki kandydat winien być przekonany do racji królewskich, które miał wspieraćs ${ }^{43}$. Mile też zapewne widziana była taka deklaracja nominowanego; sam M. Poniatowski, gdy został prymasem, deklarował, że jako prymas uczyni wszystko, czego celem będzie „wierność z miłością ku królowi i Oyczyźnie” ${ }^{4}$.

Oprócz przymiotów osobistych kandydata przy jego wyniesieniu do godności brano również pod uwagę opinię środowiska, województwa, prowincji. Raczej starano się wybierać osoby mające $\mathrm{w}$ nim niekoniecznie pierwszorzędna, ale przynajmniej ustaloną solidną pozycję. Akceptacja ogółu społeczności lokalnej dla nominowanego była pożądana. Dążenie do obsadzania stanowisk politycznych osobami myślącymi o ojczyźnie, a nie tylko o własnych potrzebach, płynące $\mathrm{z}$ „dołu”, stosunkowo łatwo było przyjmowane w otoczeniu Stanisława Augusta. Nawet chyba cieszono się,

40 Por. ibidem, k. 15, M. Poniatowski do G. Karwosieckiego, [Płock?] 23 II 1782.

41 BCz., rkps 737, s. 3, [M.] Walewski do Stanisława Augusta, [Kraków] 18 XI 1779.

42 Por. AGAD, AEP, rkps 121, k. 41, M. Poniatowski do Macieja Sołtyka wojewody sandomierskiego, [Płock] 3 VII 1784; ibidem, M. Poniatowski do Jana Małachowskiego starosty opoczyńskiego, [Płock] 3 VII 1784.

${ }^{43}$ Por. ibidem, k. 44, M. Poniatowski do [Józefa] Radzickiego podkomorzego zakroczymskiego, [Płock] 13 VIII 1784.

${ }_{44}$ Ibidem, k. 52, M. Poniatowski do [Stefana?] Łubieńskiego kanonika gnieźnieńskiego, [Płock] 10 XI 1784. Por. ibidem, k. 55, M. Poniatowski do Tomasza Dłuskiego podkomorzego lubelskiego, [Warszawa?] 29 XII 1784. 
gdy „miejscowa” szlachta nie chciała, by daną ziemię, i zarazem Rzeczpospolita, reprezentował człowiek niegodny, mogący swą postawą skompromitować współobywateli. W tym punkcie zbiegały się interesy średniej szlachty „prowincji” z interesem dworu królewskiego, który mimo wszystko, przynajmniej w województwach kresowych, nie mając w nich silnej pozycji, musiał bardziej niż opozycja dbać o dobór kandydatów do godności senatorskich. Jeżeli taka pojawiająca się na horyzoncie osoba miała dodatkowo pewne zaplecze polityczne $\mathrm{w}$ postaci rodziny i przyjaciół - w czym też ujawniała się „zdatność" kandydata - wówczas zyskiwał on na znaczeniu, albowiem mógł zapewnić wpływy i przeciwstawić się opozycjonistom zazwyczaj związanym z możnymi rodami ${ }^{45}$. Działanie tego mechanizmu można dostrzec również w odniesieniu do kariery L.M. Świeykowskiego.

Stanisław August wiedział, że złymi i nielubianymi, a tym bardziej narzuconymi kandydatami akceptacji dla swych działań nie zdobędzie. Takie negatywne skojarzenia budzili również kandydaci zyskujący wsparcie moskiewskie $^{46}$. Tu wystarczająco wymownymi i znanymi przykładami byli Adam Poniński ${ }^{47}$ i, mimo wszystko dużo bardziej od niego wartościowy człowiek, Antoni Tyzenhauz ${ }^{48}$. Warto zauważyć, że Stanisław August - chociaż to byli jego zwolennicy, a przynajmniej ten ostatni - stosunkowo łatwo przyjął ich upadek ${ }^{49}$. Tu także morale, choć werbalnie rzadko wspominane, mogło decydować niekiedy o odrzuceniu kandydata bądź zaprzestaniu jego wspierania. Starano się również wyperswadować nadmierne ambicje kandydatów, lecz w tym wypadku nie odrzucano ich, ale odwoływano się do ich cierpliwości ${ }^{50}$.

Wspomniano już, że istotnym argumentem przemawiającym za kandydatem były jego zasługi dla „domu naszego" na drodze dotychczasowej jego

45 Por. AGAD, AEP, rkps 121, k. 8, M. Poniatowski do Franciszka Kęszyckiego kasztelana gnieźnieńskiego, [Płock] 14 XI 1781; BCz., rkps 921, s. 435, Antoni Dziekoński do Stanisława Augusta, b.d. i m.; BCz., rkps 919, s. 87, [Ignacy?] Aksamitowski do NN, Kadyjowce 15 IV 1780.

46 Por. np. BCz., rkps 737, s. 161, NN do Stanisława Augusta?, Tarnów 3 VIII 1782.

47 Por. Z. Zielińska, Poniński Adam, w: PSB, t. 27, Wrocław 1983, s. 504-508; R. Chojecki, Stanisław August a proces Adama Ponińskiego, „Przegląd Historyczny” 1972, 63, s. 31-34.

48 Por. S. Kościałkowski, Antoni Tyzenhauz, t. 1, Londyn 1970, s. 93-139 i 140-164; ibidem, t. 2, s. 325-340.

49 Por. Z. Zielińska, Poniński Adam, s. 509-510; R. Chojecki, op. cit., s. 34-39; S. Kościałkowski, op. cit., t. 2, s. 462-475, 535-542.

50 Por. np. BCz., rkps 925, s. 32, Pius Kiciński do Stanisława Augusta, Warszawa 24 II 1787; AGAD, AEP, rkps 121, k. 30, M. Poniatowski do [?] Karwowskiego regenta koronnego, [Płock] 30 VII 1783; ibidem, k. 30, M. Poniatowski do Kajetana Czetwertyńskiego, [Płock] 30 VII 1783; ibidem, k. 30v, M. Poniatowski do [Jana Chryzostoma] Dąbskiego kasztelana inowrocławskiego, [Płock] 30 VII 1783. 
posługi ${ }^{51}$, o czym pisano wprost do „zacnego" „i wielce ode mnie estymowanego" [Dionizego] Mniewskiego ${ }^{52}$. Zasługi te przypuszczalnie wartościowano, szacując wyżej te, w których widziano, że były też wynikiem współpracy i silniejszych więzów danej osoby z władca, również tych o charakterze osobistym ${ }^{53}$, które wzmacniały pozycję kandydata w otoczeniu króla. A jeśli dodatkowo były ugruntowane więzami ideologicznymi, to stawały się szczególnie cenne. Wszak stronnicy króla, co warto zauważyć, chyba - poza urzędami, które jednak raz na długi czas jako taka nagroda mogły przypadać - niewiele de facto otrzymywali i w zasadzie tylko nieliczni, "przodownicy” w województwach na takie wyższe wyróżnienia mogli liczyć.

Wspólny interes związany z Rzecząpospolita, łączący króla z kreowanymi przez niego senatorami, przy właściwym doborze osób obdarzonych pewnymi talentami mógł przynieść korzyści wszystkim. Zakładając, że większość nominowanych myślała tak, jak wojewoda krakowski Piotr Małachowski, który pisał do króla, że od czasu, gdy otrzymał „krzesło”: „nic dla siebie nie czynię", a wszystko z myślą o wspieraniu planów królewskich ${ }^{54}$, można było stopniowo reformować państwo polsko-litewskie. Takie myślenie, jak się wydaje, nie było bynajmniej rzadkie i niekoniecznie nieszczere. Hasło posługi publicznej, pracy „dla dobra publicznego z ujmą nawet prywatnego" było deklarowane właściwie przy każdej okazji przez stronników króla, towarzyszyło kandydatom do poselstwa, do funkcji deputackiej i do innych urzędów bądź rang ${ }^{55}$. Takie deklaracje były składane przez L.M. Świeykowskiego, ale też przez innych, m.in. Michała Walewskiego ${ }^{56}$. Istotne jest, że większość stronników królewskich na senatorskich urzędach zdawała sobie sprawę z zależności politycznych Rzeczypospolitej i wiedziała, że w zaistniałych okolicznościach proces jej naprawy nie będzie

51 AGAD, AEP, rkps 121, k. 14, M. Poniatowski do NN, [Płock] 14 I 1782; ibidem, k. 21, M. Poniatowski do L. Zielińskiego, [Płock] 17 XII 1782.

52 Ibidem, k. 21, M. Poniatowski do Piotra Sumińskiego kasztelana kowalskiego, [Płock] 26 XII 1782. Inne przypadki, ibidem, k. 31-31v, M. Poniatowski do [?] Sierakowskiego, [Płock] 12 IX 1783.

53 BCz., rkps 921, s. 437, A. Dziekoński do Stanisława Augusta, b.m. 9 VII 1784.

54 BCz., rkps 927, s. 117-118, P. Małachowski do Stanisława Augusta, Niedźwiedź 16 VII 1785.

55 Por. np. AGAD, AEP, rkps 121, k. 17v, M. Poniatowski do [Ignacego] Stadnickiego cześnika krakowskiego, [Płock] 27 VII 1782; BCz., rkps 927, s. 159, Jacek Małachowski do Stanisława Augusta, Sitków? 10 II 1787; ibidem, s. 393, Antoni Michałowski podkomorzy krakowski do Stanisława Badeniego, b.m. 22 III 1788. Trochę inaczej trzeba traktować treści przysiąg, one też mają swój wydźwięk. Por. D. Rolnik, O wartości i znaczeniu przysięgi "urzędniczej" $i$ "honorowej" w czasach stanistawowskich. Między honorem, obowiazkiem a prywata - od sacrum do profanum?, w: Staropolski oglad świata. Kultura staropolska - poszukiwanie sacrum odnajdowanie profanum, red. B. Rok, F. Wolański, Toruń 2013, s. 468-493.

56 BCz., rkps 737, s. 3, [Michał] Walewski do Stanisława Augusta, [Nota] b.m. 18 XI 1779. 
szybki. Cieszono się nie tyle z sukcesów osiągniętych na sejmie, ile z tego, że zrobiono na nim stosunkowo niewiele rzeczy złych ${ }^{57}$.

Stanisław August - przynajmniej teoretycznie - dobrze wiedział, jak budować stronnictwo, które w końcu przeważy na szali walki o dobro państwa. Naturalną do tego drogą było w jego mniemaniu nagradzanie urzędami tych, którzy do tego celu dążyli, jasno więc deklarował: urzędy "osobom dobrze nam i Rzpltej zasłużonym konferować będziemy" 58 . Władca w pewnych województwach nie miał większych szans w otwartej rywalizacji z opozycją, np. na niektórych sejmikach w województwach południowo-wschodnich kresów Rzeczypospolitej. Sile fizycznej, przykładowo Franciszka Ksawerego Branickiego, co było widoczne jeszcze w 1788 r. na sejmikach poselskich ${ }^{59}$, mógł przeciwstawić grupę średniej szlachty, która hasłami patriotycznymi i swym autorytetem mogła niwelować przewagę "magnatów”. Sukces reform Sejmu Wielkiego to właśnie sukces tej grupy, która, w istocie nie patrząc na możnych, ale też czując odpowiedzialność za państwo, opowiedziała się za jego reformami, niekiedy także wbrew woli króla. To Stanisław August stworzył czy wykreował tę grupę polityków. Stała się ona, tak jak chciał, pragnącą dobra Rzeczypospolitej i działającą dla tego celu - a przeciwko tym, którzy jej zdaniem poszli w innym kierunku.

Ideologia głosząca „dobro Ojczyzny” odgrywała coraz większą rolę w pozyskiwaniu sojuszników w działaniach politycznych. Nieprzypadkowo Czartoryscy uważali, że zwolennicy dworu są „wrogami Ojczyzny", którzy przedkładają „widoki osobiste nad interes narodu”60, bowiem tylko takim językiem można było trafić do obywateli. W 1788 r. na sejmikach poselskich nawet ambasador rosyjski Otto Stackelberg $\mathrm{W}$ „imię miłości Ojczyzny" pisał do S.Sz. Potockiego, by ten nie dopuszczał do wyboru posłów małostkowych, kłótliwych ${ }^{61}$. Frazeologia patriotyczna jakkolwiek różnie wpływająca na postawy obywatelskie - w przypadku tego, co wydarzyło się w czasach stanisławowskich, a co zapoczątkował Stanisław August, kreując swoje stronnictwo w oparciu o grupę nowych senatorów, pozytywnie oddziaływała na szlachtę - obywateli, bowiem za niekiedy pustymi hasłami szła myśl polityczna: skoro wszyscy głoszą,

57 AGAD, AEP, rkps 121, k. 20, M. Poniatowski do Józefa Jerzego Hilzena wojewody mścisławskiego, [Płock] 20 XI 1782.

${ }^{58}$ Cyt. za T. Zielińska, Kwestia bezpłatności urzędów publicznych w Rzeczypospolitej XVIXVIII w., w: Władza i społeczeństwo w XVI i XVII w. Prace ofiarowane A. Maczakowi w sześćdziesiata rocznice urodzin, red. M. Kamler et al., Warszawa 1989, s. 209.

${ }_{59}$ Por. J. Michalski, op. cit., s. 223, 227.

60 Por. ibidem, s. 223.

61 Ibidem, s. 232-234. 
że kochają ojczyznę, to jest to słuszne, należy jeszcze tylko zadać pytanie, co to właściwie znaczy. Na tej płaszczyźnie także z czasem powstał dość powszechnie aprobowany program naprawy państwa ${ }^{62}$, przyjmowany również przez tych, którzy do 1788 r. jawili się jako wrogowie króla.

Przedstawiony schemat, choć w swych meandrach może być nader skomplikowany, jest prosty, przy tym wydaje się trafny, wyjątki, które znajdziemy od tej reguły, tylko ją potwierdzają. Coraz powszechniejsze stawało się mniemanie, że dopiero posługa dla ojczyzny - i tylko ona - upoważniała do dopominania się o nagrodę $\mathrm{w}$ postaci funkcji czy urzędu. Wystarczy przejrzeć zapisy konstytucji Sejmu Wielkiego ${ }^{63}$, ale też i późniejsze projekty targowiczan, z których wynika, że na pierwszym miejscu stawiano posługę w komisjach cywilno-wojskowych, następnie w Trybunale i w sejmie, a dopiero potem można było starać się o krzesło w senacie ${ }^{64}$. Z pewnością pochodzenie z rodziny magnackiej nie stanowiło już najważniejszego argumentu na drodze kariery senatorskiej, choć takie myślenie było jeszcze silnie zakorzenione w świadomości szlachty czasów Sejmu Wielkiego. Zauważał to L.M. Świeykowski, dziękując królowi za swe wyniesienie do godności wojewody podolskiego, pisał wówczas, że dawne rodziny możnych miały „pierwsze prawo do łask Pańskich", a Stanisław August wbrew temu wskazał na niego ${ }^{65}$.

Przypadek kariery L.M. Świeykowskiego, jakkolwiek nie w pełni modelowy, mieści się $\mathrm{w}$ przedstawionym schemacie i nie jest też odosobniony. W podobny sposób do godności senatorskich doszli m.in. Rafał i Gedeon Jeleńscy ${ }^{66}$, Adam Chmara ${ }^{67}$ czy Michał Walewski ${ }^{68}$. Wszyscy oni

${ }^{62}$ Potwierdzają to badania J. Koweckiego przeprowadzone na grupie posłów debiutantów z 1790 r. Zauważał on, że byli to ludzie wskazani oraz związani z królem i była to świadoma działalność Stanisława Augusta. Por. J. Kowecki, Posłowie debiutanci na sejmie czteroletnim, w: Wiek XVIII Polska i świat. Księga poświęcona Bogusławowi Leśnodorskiemu, red. A. Zahorski, Warszawa 1974, s. 203.

63 Np. Seymiki. Prawo uchwalone dnia 24 marca 1791, rozdz. VII, p. 3 [Reprint Kórnik 1985], s. 40, mówiło, że ten, kto wcześniej żadnej funkcji nie pełnił (tu wymieniano funkcję komisarza porządkowego), nie mógł zostać posłem.

${ }^{64}$ BK, rkps 1188, k. 7, [L.M. Świeykowski] Myśli obywatelskie nad ustanowieniem formy rządu republikańskiego, pisał tu: „Do wakujących krzeseł wojewódzkiego i kasztelańskiego nie mógłby się nikt w kandydacji mieścić, kto by [...] trzech funkcji poselskich, a jednej na trybunał deputackiej nie odbył".

65 BCz., rkps 730, s. 849, L.M. Świeykowski do Stanisława Augusta, Kołodno 23 XI 1790.

66 Por. Nacjonalinyj Gistoricznyj Archiu Bielarusij w Mińsku [dalej: NGAB], f. 319, op. 1, rkps 32a, k. 387-388, Wywód familii Jeleńskich, [Mińsk] 27 VIII 1802; E. Rabowicz, Jeleński Gedeon, w: PSB, t. 9, Wrocław 1960-1961, s. 140-141; E. Rabowicz, Jeleński Rafat, w: PSB, t. 9, s. 144; D. Rolnik, Województwo mińskie i Jeleńscy w życiu publicznym Rzeczypospolitej w latach 1764-1795 w świetle ich korespondencji, Katowice 2018, s. 151-202.

67 H. Mościcki, Chmara Adam, w: PSB, t. 3, Kraków 1937, s. 315-316.

68 Por. H. Żerek-Kleszcz, Michał Walewski podkomorzy krakowski i wojewoda sieradzki i jego korespondencja z królem Stanisławem Augustem 1777-1787, „Rocznik Łódzki” 2001, 48; 
w pewnym momencie spełniali - zdaniem Stanisława Augusta - warunek działania dla dobra Rzeczypospolitej i deklarowali, bynajmniej niebezwarunkowo, w zasadniczych kierunkach poparcie dla polityki króla. Spełniali także warunki potrzebne, by taką politykę realizować, co wydaje się naturalne, a więc w swych środowiskach zajmowali znaczącą pozycję, natomiast pod względem majątkowym mogli się zbliżać do statusu magnata, co było dobrze widziane, albowiem zwiększało możliwości rywalizacji z opozycją na sejmikach, choć, zaznaczmy, nigdy nie był to cel nadrzędny w polityce króla, lecz tylko środek do budowy niższych struktur jego stronnictwa. Wymieniona grupa senatorów odznaczała się także podobnymi cechami charakterologicznymi. Byli to ludzie, mniej lub bardziej, ale zasadniczy, mający własne zdanie, umiejący argumentować swe racje, działający zawsze energicznie i koncentrujący uwagę przede wszystkim w województwach, z których albo się wywodzili, albo pozyskali w nich wpływy. Do tych cech należy przyłożyć, rzecz jasna, odpowiednią miarę - taka ich postawa ujawniała się w sprawach wewnętrznych Rzeczypospolitej, gdzie ich polemistami mieli być kierujący opozycją antykrólewska, natomiast inaczej zachowywali się w relacjach z przedstawicielami Rosji ${ }^{69}$.

Na pytanie o skalę funkcjonowania tego mechanizmu kreowania grupy senatorów przez Stanisława Augusta wobec braku badań podstawowych trudno jednoznacznie odpowiedzieć. Dopiero w miarę dokładna analiza awansów - przede wszystkim kulis zabiegów o awanse na poszczególne szczeble kariery, wpływu ambasadorów moskiewskich na nominacje czy zasady przypisywania pewnych krzeseł możnym rodom, co niekiedy akceptował Stanisław August - całej tej grupy senatorskiej, liczącej 407 osób $^{70}$, może dać satysfakcjonującą odpowiedź. Wówczas będziemy mogli ustalić, czy pokazany mechanizm był trwałą zasada, według której postępował Stanisław August przy kreowaniu senatorów, czy

H. Żerek-Kleszcz, Nominacje senatorskie Stanisława Augusta Poniatowskiego w okresie Rady Nieustającej, „Przegląd Nauk Historycznych” 2006, 5, 1, s. 213, 217-219, 226. Tu warto odnotować, że M. Walewski został wybrany w istocie przed głosowaniem w Radzie Nieustającej, co nie było bynajmniej jednorazowym przypadkiem. Por. ibidem.

69 Por. np. D. Rolnik, Portret szlachty czasów stanisławowskich, epoki kryzysu, odrodzenia i upadku Rzeczypospolitej w pamiętnikach polskich, Katowice 2009, s. 335-372.

${ }^{70}$ Statystyka autora. Możliwe są tu zdublowane postacie, można też odliczyć tych, którzy ostatni awans uzyskali za Augusta III, a uwzględniając to, uzyskamy grupę liczącą co najmniej 350 osób. Badania prosopograficzne takiej grupy przy tym zasobie źródeł, którym obecnie dysponujemy, przekraczają możliwości jednego badacza, wszak waga problemu jest naprawdę duża. Tu być może kryje się odpowiedź na pytania o funkcjonowanie oraz trwałość narodu polskiego i litewskiego w XIX w., co intuicyjnie jest wskazywane. Wydaje się, że dobrym przykładem badań tej grupy są rozważania H. Żerek-Kleszcz, Nominacje senatorskie, s. 209-233. 
- i pod wpływem jakich czynników - ulegał on zmianom i modyfikacjom. Natomiast z pewnością możemy stwierdzić, że ten mechanizm Stanisław August chciał stosować i według niego postępować. Ów władca umiał wynajdywać ludzi zdolnych do realizacji powierzanych przez niego misji bądź zadań, potrafił rozgrywać konflikty personalne między politykami stanowiącymi ówczesną elitę i je wygrywać. Zdaje się to wyraźnie pokazywać kształtowanie stanu senatorskiego, nie należy jednak zapominać o pewnych naturalnych - już sygnalizowanych - w tamtej stanisławowskiej Rzeczypospolitej ograniczeniach. Częściowo właśnie z nich wynikały błędne wybory personalne Stanisława Augusta, ale także - wychodząc nieco poza poruszany tu temat - nie w tym tkwiła słabość budowanego przez króla stronnictwa, a przynajmniej nie w ludziach, którzy je tworzyli na tym senatorskim szczeblu. Owe elity król wyłowił dobrze, a problem, jak się wydaje, tkwił w jego osobistej niekonsekwencji i słabości, co dostrzegali wybrani przez niego senatorowie. Widzieli oni te niedoskonałości osobowości Stanisława Augusta przy tworzeniu królewskiego programu naprawy Rzeczypospolitej i chyba jeszcze wyraźniej przy próbach jego realizacji, kiedy to pryncypia zostały zupełnie zatracone, począwszy od zasady sojuszu z Moskwa, do podważania podstawowych prerogatyw narodu szlacheckiego, przy czym w obu przypadkach nie tyle ważny był fakt odstąpienia od nich, co sposób, w jaki to uczyniono. To było powodem odejścia od Stanisława Augusta L.M. Świeykowskiego i innych „królewskich" senatorów po uchwaleniu Konstytucji 3 maja, nie wcześniej¹.

Widoczna słabość stronnictwa królewskiego może być przewrotnie traktowana jako argument przeciw współcześnie stawianej przez opozycję tezie, że Stanisław August tworzył sobie zaplecze z ludzi miałkich oraz zupełnie mu oddanych i zależnych od niego „pieczeniarzy”. W świetle tego, co zostało pokazane i zasygnalizowane, taką tezę można uznać, owszem, za propagandowe hasło, ale $\mathrm{w}$ istocie niemające silnego uzasadnienia. Stanisław August po prostu był zmuszony do szukania ludzi, na których mógłby oprzeć swoją politykę. Wiedział, kogo ma w kraju za przeciwnika, a zatem musiał pozyskiwać osoby, które pewne braki w pozycji ekonomicznej nadrabiałyby innymi przymiotami lub cechami. Liczył się zwłaszcza silny charakter oraz nieuleganie wpływom najsilniejszych rodów magnackich - cechy te przekonywały króla do danej osoby i utwierdzały go w przekonaniu, że warto ją promować. Przedstawione kryteria,

${ }_{11}$ Por. np. BK, rkps 1188, k. 1-2, 17-18, [Protestacja przeciwko Konstytucji 3 maja i akces do konfederacji targowickiej L.M. Świeykowskiego, oblata Krzemieniec 30 VII 1792], z pełnym uzasadnieniem stanowiska. Por. też D. Rolnik, Michat Zaleski - moralne dylematy targowiczanina. O postawie politycznej marszałka konfederacji targowickiej województwa brzesko-litewskiego w latach 1788-1793, „Wieki Stare i Nowe” 2003, 3, s. 95-97, 100. 
którymi kierował się Stanisława August, rozważając kogo nominować na krzesło senatorskie, owszem, zawierają oddanie i przywiązanie do domu panującego, ale prawie zawsze współgra ono z celem nadrzędnym - „dobrem Rzeczypospolitej”. A to sprawiało i usprawiedliwiało - czego król chyba miał świadomość - możliwość odstępstwa i pozwalało ewentualny dług wdzięczności kasować. Przykład L.M. Świeykowskiego jest tu bardzo wymowny. W jego mniemaniu król zdradził Rzeczpospolita, naród szlachecki, a to zwalniało go od wszelkich zobowiązań wobec niego. Stanisław August wielokrotnie deklarował, jakich chce mieć obywateli i we wspominanych kryteriach nigdzie nie znaleziono jego słów zapisanych na papierze, sugerujących, że kierowała nim chęć „,korumpowania” woli osób nominowanych do funkcji senatorskich. Po prostu nie mógł tego robić na większą skalę, bo tak postępowała magnacka opozycja, z którą walczył dla dobra Rzeczypospolitej. Jednakże pojawienie się u króla takiej myśli szukania zwolenników można by uznać za naturalne. W ten sposób bowiem myśleli współcześni, a przynajmniej niektórzy przedstawiciele opozycji. Również dla dobrego obserwatora ówczesnej rzeczywistości, a takim był z pewnością Stanisław August, oczywiste było, że tak postępować nie można, a na pewno nie można jawnie tego okazywać czynem ani werbalizować takich myśli. Stanisław August był chyba pierwszym i, niestety, ostatnim królem Rzeczypospolitej, który wiedział i miał pełną świadomość, jaką moc może mieć opinia publiczna, nawet ta ograniczona tylko do mas szlacheckich.

Stanisław August z pewnością starał się dobierać do krzeseł senatorskich ludzi nieprzypadkowych. Te jednostkowe, wybrane tu do analizy postaci senatorów - pozostawiając na boku ich wybory polityczne - należy wszystkie zakwalifikować do grona osób wartościowych, politycznie obdarzonych sporymi talentami. Stanisław August z pewnością posiadał umiejętność - nie licząc ewidentnych pomyłek - selekcjonowania dobrych obywateli, niestety, sam niekiedy zapominał, jakimi kryteriami kierował się przy ich wyznaczaniu. Zdarzało się, że jego postępowanie odbiegało od tych standardów, które - być może w innym czasie i w innych okolicznościach - stosował wobec kandydatów na senatorów. 


\section{BIBLIOGRAFIA (REFERENCES)}

\section{Źródła rękopiśmienne}

Archiwum Główne Akt Dawnych: Archiwum Ekonomiczne prymasa Poniatowskiego, rkps 121, Bruliony listów Michała Poniatowskiego.

Archiwum Narodowe w Krakowie: Archiwum Sanguszków, Korespondencja rkps 36, Listy do Sanguszków.

Biblioteka Jagiellońska w Krakowie: rkps 5971, Listy Świeykowskich.

Biblioteka Książąt Czartoryskich w Krakowie: rkps 682, 685, 688, 710, 730, 737, 919, 921-922, 925, 927 (Korespondencja królewska). rkps 3185-3186, Korespondencja i papiery Świeykowskich.

Biblioteka Narodowa w Warszawie: rkps 9050, t. 1, Korespondencja Świeykowskich.

Biblioteka PAN w Kórniku: rkps 1188, Opuscula L.M. Świeykowskiego. rkps 1246, 1256, t. 1, 1264, 1273, Papiery z Archiwum Świeykowskich

Biblioteka Zakładu Narodowego im. Ossolińskich we Wrocławiu: rkps 1996, 1997, Listy do Swieykowskich.

Lvivska Naukowa Biblioteka Ukrainy im. W. Stefanyka: f. 141, op. 3, rkps 438, Wywód szlachectwa Świeykowskich.

Nacjonalinyj Gistoricznyj Archiu Bielarusij w Mińsku: f. 319, op. 1 rkps 32a, Wywód familii Jeleńskich, [Mińsk] 27 VIII 1802.

\section{Źródła drukowane}

Czartoryski A.J., Pamiętniki i memoriaty polityczne 1776-1809, oprac. J. Skowronek, Warszawa 1986.

Korespondencja krajowa Stanisława Augusta z lat 1784 do 1792, wyd. B. Zaleski, Poznań 1872.

Matuszewicz M., Diarusz życia mego, t. 2, oprac. B. Królikowski, Z. Zielińska, Warszawa 1986.

Seymiki. Prawo uchwalone dnia 24 marca 1791, rozdz. VII, p. 3, [Reprint Kórnik 1985].

\section{Opracowania}

Chojecki R., Stanistaw August a proces Adama Ponińskiego, „Przegląd Historyczny” 1972, 63.

Ciara S., Senatorowie i dygnitarze koronni w drugiej połowie XVII wieku, Wrocław-WarszawaKraków 1990.

Deputaci Trybunatu Koronnego 1578-1794. Spis, cz. 5: 1751-1794, oprac. J. Trernes, Warszawa 2017.

Filipczak W., Sejm 1778 roku, Warszawa 2000.

Handelsman M., Czartoryski Adam Jerzy, w: Polski Słownik Biograficzny, t. 4, Kraków 1938.

Heleniusz E. [Iwanowski Eustachy], Rozmowy o polskiej koronie, t. 1, Kraków 1873.

Kościałkowski S., Antoni Tyzenhauz, t. 1, Londyn 1970.

Kowecki J., Posłowie debiutanci na sejmie czteroletnim, w: Wiek XVIII Polska i świat. Księga poświęcona Bogusławowi Leśnodorskiemu, red. A. Zahorski, Warszawa 1974.

Mączak A., Rządzacy i rządzeni. Władza i społeczeństwo w Europie wczesnonowożytnej, Warszawa 1986.

Michalski J., Sejmiki poselskie 1788 roku, w: J. Michalski, Studia Historyczne z XVIII i XIX wieku, t. 1, Warszawa 2007.

Mościcki H., Chmara Adam, w: Polski Stownik Biograficzny, t. 3, Kraków 1937. 
Pułaski K., Kronika polskich rodów szlacheckich Podola, Wołynia i Ukrainy, t. 2, oprac. T. Epsztein, S. Górzyński, Warszawa 1991.

Rabowicz E., Jeleński Gedeon, w: Polski Słownik Biograficzny, t. 9, Wrocław 1960-1961.

Rabowicz E., Jeleński Rafat, w: Polski Słownik Biograficzny, t. 9, Wrocław 1960-1961.

Rolnik D., Leonarda Marcina Świeykowskiego (1721-1793) ostatniego wojewody podolskiego życie codzienne i publiczne oraz jego myśli o Rzeczypospolitej, Katowice 2016.

Rolnik D., Michał Zaleski - moralne dylematy targowiczanina. O postawie politycznej marszatka konfederacji targowickiej województwa brzesko-litewskiego w latach 1788-1793, „Wieki Stare i Nowe" 2003, 3.

Rolnik D., O wartości i znaczeniu przysięgi "urzędniczej" $i$,honorowej" w czasach stanisławowskich. Między honorem, obowiazkiem a prywata - od sacrum do profanum?, w: Staropolski oglad świata. Kultura staropolska - poszukiwanie sacrum, odnajdowanie profanum, red. B. Rok, F. Wolański, Toruń 2013.

Rolnik D., Portret szlachty czasów stanisławowskich, epoki kryzysu, odrodzenia i upadku Rzeczypospolitej w pamiętnikach polskich, Katowice 2009.

Rolnik D., Sejmiki poselskie drugiej połowy panowania Stanisława Augusta. O czynnikach i motywacjach decydujacych o wyborze postów sejmowych, w: Po unii - sejmiki szlacheckie w Rzeczypospolitej XVI-XVIII wieku, red. H. Lulewicz, M. Wagner, Siedlce 2013.

Rolnik D., Województwo mińskie i Jeleńscy w życiu publicznym Rzeczypospolitej w latach 1764 1795 w świetle ich korespondencji, Katowice 2018.

Rosner A., Mniszech Michat Jerzy Wandalin (1742-1806), w: Polski Słownik Biograficzny, t. 21, Wrocław 1976.

Rymszyna M., Karaś Kazimierz, w: Polski Słownik Biograficzny, t. 12, Wrocław 1966-1967.

Stefaniuk M., Teoria elit Vilfreda Pareta, Lublin 2001.

Stroynowski A., Opozycja sejmowa w dobie rządów Rady Nieustającej. Studium z dziejów kultury politycznej, Łódź 2005.

Szczygielski W., Lubomirski Stanisław, w: Polski Słownik Biograficzny, t. 18, Wrocław 1973.

Tomasza Święckiego historyczne pamiątki znamienitych rodzin i osób dawnej Polski, t. 2, oprac. J. Bartoszewicz, Warszawa 1859.

Urzędnicy podolscy XIV-XVIII wieku. Spisy, oprac. E. Janas [et. al.], Kórnik 1998.

Zielińska T., Kwestia bezpłatności urzędów publicznych w Rzeczypospolitej XVI-XVIII w., w: Władza i społeczeństwo w XVI i XVII w. Prace ofiarowane A. Mączakowi w sześćdziesiata rocznice urodzin, red. M. Kamler et al., Warszawa 1989.

Zielińska T., Magnateria polska epoki saskiej, Wrocław 1977.

Zielińska Z., Poniński Adam, w: Polski Stownik Biograficzny, t. 27, Wrocław 1983.

Znamierowski Cz., Elita i demokracja, Warszawa 1946.

Żerek-Kleszcz H., Michał Walewski podkomorzy krakowski i wojewoda sieradzki i jego korespondencja z królem Stanisławem Augustem 1777-1787, „Rocznik Łódzki” 2001, 48.

Żerek-Kleszcz H., Nominacje senatorskie Stanisława Augusta Poniatowskiego w okresie Rady Nieustajacej, „Przegląd Nauk Historycznych” 2006, 5, 1.

\section{ABSTRACT}

The purpose of the article is to analyse the manner in which the political elites were created and the paths which led to those elites. The focus is on the career of Leonard Marcin Świeykowski, which is compared to a number of other cases of senatorial careers, inter alia those of Gedeon Jeleński and Adam Chmara. All of these people produced similar family archives. These sources have allowed a reconstruction of the mechanisms of their careers, which are substantially similar. This is clearly discernible in King Stanisław Augustus's 
creation of the circle of royal supporters. Submissiveness toward the decision-making centre was not the sole factor which determined a career. Such features as entrepreneurship and intelligence were of greater relevance to a career, whereas noble birth and the inherited estate were of secondary relevance. Another crucial feature had to do with an attitude which expressed interest in the welfare of the state and fellow citizens, which may be associated with the establishment of a specific political agenda whose purpose was to reform the Polish Commonwealth.

Key words: Stanisław Augustus, the elite of the Polish Commonwealth, public life, Leonard Marcin Świeykowski

\section{NOTA O AUTORZE}

Dariusz Rolnik - doktor habilitowany, pracownik Instytutu Historii Uniwersytetu Śląskiego w Katowicach (Zakład Historii Nowożytnej XVI-XVIII w.). Zajmuje się historią Rzeczypospolitej czasów Stanisława Augusta, a szczególnie dziejami społeczeństwa szlacheckiego tego okresu. Z tą tematyką wiążą się jego publikacje, m.in.: Szlachta koronna wobec konfederacji targowickiej (maj 1792 - styczeń 1793) (Katowice 2000); Portret szlachty czasów stanisławowskich, epoki kryzysu, odrodzenia i upadku Rzeczypospolitej w pamiętnikach polskich (Katowice 2009); Leonarda Marcina Świeykowskiego (1721-1793) ostatniego wojewody podolskiego życie codzienne i publiczne oraz jego myśli o Rzeczypospolitej (Katowice 2016); Województwo mińskie $i$ Jeleńscy w życiu publicznym Rzeczypospolitej w latach 1764-1795 w świetle ich korespondencji (Katowice 2018). E-mail: dariusz.rolnik@us.edu.pl 